\title{
WORK ASPECT DIMENSION AND IT'S INFLUENCE TOWARDS EMPLOYEE'S PERFORMANCE IN HOSPITAL ORGANIZATION
}

\author{
Muhamad Rifa'i, Rr Nugraheni Suci Sayekti, Emilia \\ Faculty of Economics, University of Tribhuwana Tunggadewi Malang \\ rifaiunitri@gmail.com
}

\begin{abstract}
This research aims to know the influence of aspect dimensions working areas which include salaries, employment, promotion, supervisors, and coworkers, either simultaneously or partially. Sample research determined are purposive random sampling. The sample in this study of 53 employees non paramedics. The research of the variable is the variable which consists of salary, employment, promotion, supervisor, and co-workers. While the variable bound to the performance of the employees. Data analysis was done with descriptive analysis and inferensial with multiple linear regression analysis. Research shows aspects of work that includes salaries, employment, promotion, supervisors, co-workers and the simultaneous effect of non employee performance significantly to paramedics. The second hypothesis test indicates that the variable is only partially a significant colleague, while for variable salaries, employment, promotion, and the supervisor was not significant. While the third hypothesis suggests that the most dominant variables obtained from the standardized coefficients.
\end{abstract}

Keywords: Dimensional Aspects of The Work, The Performance of Employees.

\section{DIMENSI ASPEK KERJA SERTA PENGARUHNYA TERHADAP KINERJA PEGAWAI PADA ORGANISASI RUMAH SAKIT}

\author{
Muhamad Rifa'i, Rr Nugraheni Suci Sayekti, Emilia \\ Fakultas Ekonomi, Universitas Tribhuwana Tunggadewi \\ rifaiunitri@gmail.com
}

\begin{abstract}
Penelitian ini bertujuan mengetahui pengaruh dimensi-dimensi aspek lingkungan kerja meliputi gaji, lapangan pekerjaan, promosi, para pengawas, dan para rekan kerja, baik secara bersamaan maupun ecara parsial. Sampel penelitian yang ditenukan menggunakan purposive random sampling. Sampel dalam penelitian ini adalah 53 pegawai non-paramedis. Variabel penelitian adalah variabel yang terdiri dari gaji, lapangan pekerjaan, promosi, para pengawas, dan rekan-rekan kerja. Variabel terkait dengan kinerja para pegawai. Analisis data dilakukan dengan analisis deskriptif dan inferensial dengan analisis regresi berganda. Penelitian menunjukkan aspek-aspek kerja yang meliputi gaji, lapangan pekerjaan, kenaikan jabatan, para pengawas, rekanrekan kerja, dan efek simultan dari kinerja non-pegawai yang signifikan terhadap
\end{abstract}


paramedis. Uji hipotesis kedua mengindikasikan bahwa variabel hanya bersifat parsial terhadap seorang kolega signifikan, sementara variabel gaji, lapangan pekerjaan, kenaikan jabatan, dan pengawas tidaklah signifikan. Sementara hipotesis ketiga menunjukkan bahwa variabel-variabel paling dominan diperoleh dari koefisienkoefisien terstandardisasi.

Kata Kunci: Aspek-aspek Dimensional Kerja, Kinerja Pegawai

\section{PENDAHULUAN}

Manajemen sumber daya manusia memegang peran penting dalam sebuah organisasi, baik itu organisasi pemerintahan, industri, pendidikan, sosial, dan sebagainya. Apabila sumber daya manusia dalam organisasi dikelola dan dimanfaatkan dengan baik, maka organisasi tersebut akan mampu menjalankan roda organisasi secara maksimal (Baedhowi, 2007). Tenaga kerja adalah orangorang yang bekerja pada suatu organisasi, baik pada instansi Pemerintah maupun pada perusahaanperusahaan atau usaha- usaha sosial dimana ia memperoleh suatu balas jasa tertentu. Tenaga kerja dapat diartikan sebagai buruh, pegawai, karyawan, pekerja yang pada hakekatnya mempunyai maksud yang sama. Dalam membina dan mewujudkan pegawai dengan disiplin yang tinggi banyak sekali faktor-faktor yang mempengaruhinya baik faktor dari dalam dirinya sendiri maupun dari luar dirinya. Misalnya keamanan kerja, lingkungan kerja yang nyaman, penghasilan yang cukup, semuanya itu dapat menggerakkan karyawan untuk bekerja dengan penuh perhatian dan kerelaan tanpa adanya perasaan terpaksa dan tertekan serta mendapatkan kepuasan yang pada akhirnya akan meningkatkan kinerja.
Kinerja pegwai atau karyawan perlu diperhatikan oleh organisasi maupun manajemen, karena kinerja merupakan kriteria untuk mengukur keberhasilan organisasi dalam memenuhi kebutuhan anggotanya. Untuk itu manajemen harus senantiasa memonitor kinerja para tenaga kerja, karena hal itu akan mempengaruhi tingkat absensi, perputaran tenaga kerja, keluhan-keluhan dan masalahmasalah yang lainnya (Handoko, 1992). Masalah kinerja merupakan hal yang sangat personal, artinya yang paling bisa merasakan hanyalah yang bersangkutan saja dan sifatnya tidak selalu sama antara orang yang satu dengan orang yang lainnya.Walaupun keduaya berada pada kedudukan dan jabatan yang sama, kedua orang tersebut tidak akan mungkin mempunyai tingkat kepuasan yang sama sulit diduga. Yang satu terpuaskan dari gaji ynag diterimanya, tetapi yang satunya lagi mungkin telah terpuaskan karena ia merasa bahwa kemampuan dan keahliannya mendapat perhatian.

Dengan memperhatikan dimensi aspek kerja yang dapat mempengaruhi kinerja pegawai seperti gaji, pekerjaan, promosi, penyelia dan rekan sekerja akan dapat menggerakkan tingkat motivasi yang kuat sehingga akan dapat menghasilkan 
kinerja. Tingkat kinerja dapat ditunjukkan dengan hasil-hasil seperti produktivitas, perpindahan karyawan, kemangkiran karyawan, absensi karyawan, dan pengaruh lain kepuasan dalam perusahaan. Segala hal yang berkaitan dengan faktor-faktor kinerja dapat diatur sedemikian rupa dan dibuat sama untuk dikenakan pada semua karyawan tanpa terkecuali. Dengan demikian setiap orang yang telah menjadi karyawan harus menyepakati peraturan yang telah dikeluarkan oleh perusahaan tersebut. Hal ini berarti karyawan yang bersangkutan akan dapat memperoleh kepuasan kerja. Dengan karyawan yang mempunyai tingkat kepuasan yang tinggi akan menghasilkan karyawan yang produktivitasnya tinggi. Dalam penelitiannya Purmosidhi (1990), Satriyo (1997) mengungkapkan bahwa iklim organisasi berpengaruh terhadap kinerja, Widiastari (1994) menyimpulkan bahwa kinerja dipengaruhi oleh upah, promosi, pekerjaan, rekan sekerja dan supervisi. Kemudian Winarni (1995) mengungkapkan bahwa yang mempengaruhi kinerja adalah upah dan jenis tunjangan, kondisi lingkungan kerja, hubungan sosial antar karyawan, kepemimpinan dan perkembangan karir. Widiastari (1994) dalam penelitiannya menggunakan variabel bebasnya upah, promosi, pekerjaan, rekan sekerja dan supervisi serta variabel terikatnya kinerja. Rumah Sakit merupakan sarana pelayanan kesehatan tempat berkumpulnya orang sakit maupun orang sehat, atau dapat menjadi tempat penularan penyakit serta memungkinkan terjadinya pencemaran lingkungan dan gangguan kesehatan merupakan. Namun pada era Otonomi Daerah juga mulai diharapkan dapat membiayai usahanya sendiri (bersifat mandiri). Untuk mencapai tujuan tersebut, perusahaan tidak bisa lepas dari unsur tenaga kerja.

\section{LANDASAN TEORI}

Aspek kerja dapat mempengaruhi motivasi dan kepuasan kerja, karena aspek kerja tersebut dapat membentuk harapan pegawai tentang konsekuensi yang akan timbul dari tindakan. Pada pegawai akan mengharapkan imbalan, kepuasan, prestasi atas dasar persepsi mereka terhadap organisasi. Aspek kerja yang dianggap mempengaruhi kepuasan kerja oleh Gibson (1995) disebutkan: upah, pekerjaan, promosi, penyelia, rekan kerja. Robbins (1996) menyimpulkan beberapa aspek kerja yang mempengaruhi kepuasan kerja karyawan adalah: suasana kerja, penyeliaan, upah sekarang, promosi, hubungan dengan rekan sekerja dan pimpinan. Sedangkan Wexley dan Yukl (1992) menyebutkan aspek kerja yang mempengaruhi kepuasan kerja adalah : upah, pekerjaan, pengawasan, teman kerja, materi pekerjaan, jaminan kerja dan promosi. Menurut Gilmer (1966) dalam As'ad (1998) faktor-faktor kerja yang mempengaruhi kepuasan kerja adalah: promosi, keamanan kerja, gaji, perusahaan dan manajemen, pengawasan, faktor-faktor intrinsik dari pekerjaan, kondisi kerja, aspek sosial dalam pekerjaan, komunikasi dan rekan sekerja. Sedangkan Luthans 
menyebutkan faktor-faktor kerja yang dapat mempengaruhi kepuasan kerja adalah upah, pekerjaan, promosi, supervisi, rekan sekerja dan kondisi kerja.Dalam uraian berikut dibahas lima dimensi aspek kerja yang berpengaruh terhadap kepuasan kerja yaitu: gaji, pekerjaan, promosi, penyelia dan rekan sekerja.

Gaji merupakan imbalan atas hasil pekerjaan yang telah dilakukan untuk orang lain. Gaji yang mempengaruhi kepuasan kerja adalah gaji yang dianggap wajar atau adil. Heidjirahman dan Husnan (1990) memberikan ulasan tentang keadilan dalam penggajiaan bahwa keadilan harus dihubungkan antara pengorbanan (input) dengan penghasilan (output). Gaji yang rendah dapat menimbulkan moral buruk, keluhan-keluhan, memperbesar perputaran karyawan, penurunan produktivitas kerja. Imbalan berupa uang merupakan imbalan yang dianggap paling penting di tempat kerja (Stoner dan Wankel, 1986). Gaji yang buruk dapat menimbulkan moral buruk, keluhan, memperbesar perputaran pegawai dan aktivitas serikat buruh (Braid, 1991). Program kompensasi yang baik menurut Braid (1991) mempunyai ciri-ciri: Bersaing, Rasional, dan Berdasarkan kinerja. Menurut Manullang (1983) bentuk insentif menurut sifatnya ada tiga macam, yaitu: Financial Insentif, Non Financial Insentif, dan Social Insentif.

Pekerjaan dapat berpengaruh pada pekerja dan akan mengahasilkan kepuasan, motivasi intern atau organisasi, prestasi yang bermutu tinggi, tingkat kemangkiran dan perputaran tenaga kerja yang rendah
(Schein,1992). Hal ini bisa dicapai apabila: (1) Pekerjaan itu dialami sebagai sesuatu yang berarti, bermanfaat atau penting. (2) Pekerja mengalami bahwa ia bertanggung jawab atas hasil pekerjaan itu secara pribadi. (3) Pekerja dapat memastikan dengan cara yang teratur dan terandalkan bagaimana hasil uasahanya, apa saja yang telah dicapai dan hasil itu memuaskan atau tidak.

Robbins (1996) menyebutkan faktor-faktor penting yang dapat mempengaruhi kepuasan kerja salah satunya adalah pekerjaan yang secara mental menantang. Pegawai cenderung lebih menyukai pekerjaan-pekerjaan yang memberi mereka kesempatan untuk menggunakan keterampilan dan kemampuan mereka dan menawarkan beragam tugas, kebebasan, dan umpan balik mengenai betapa baik mereka mengerjakan. Karakteristik ini membuat kerja secara mental menantang. Pekerjaan yang secara mental kurang menantang menciptakan frustasi dan perasaan gagal. Pada kondisi tantangan yang sedang, kebanyakan pegawai akan mengalami kesenangan dan kepuasan.

Muatan pekerjaan itu sendiri merupakan sumber utama kepuasan pekerja. Misalnya penelitian yang berkaitan dengan pendekatan karakteristik pekerjaaan menunjukkan bahwa pekerjaan dan wewenang merupakan dua faktor motivasi utama dalam bekerja. Beberapa sumber kepuasan kerja penting yang tidak ditemukan dalam penelitian adalah pekerjaan yang menarik dan memberikan tantangan, pekerjaan yang tidak membosankan dan pekerjaan 
yang bisa memberikan status. Luthans (1992) menjelaskan hubungan antara keadaan yang diinginkan pekerja dengan dimensi dasar pekerjaan dan hasil pekerjaan itu dapat digambarkan sebagai berikut: (a) Pekerjaan dialami sebagai sesuatu yang berarti apabila pekerjaan mengharuskan para pekerja melaksanakan kegiatan yang menuntut berbagai keterampilan dan kemampuan. Pekerjaan mengharuskan penyelesaian seluruh pekerjaan dari awal hingga akhir dengan hasil yang nyata. Pekerjaan mempunyai dampak besar atas kehidupan orang lain untuk organisasi sendiri maupun luar organisasi. Sehingga ini akan menghasilkan motivasi kerja intern dan prestasi kerja yang tinggi. (b) Pekerjaan dapat menciptakan rasa tanggung jawab bila ada otonomi. Pekerjaan tersebut memberikan kepada pekerja kebebasan, kemandirian dan kebijakan dalam penjadualan pekerjaan dan menentukan pelaksanaan pekerjaan. Melaksanakan pekerjaan dengan otonomi ini dapat menghasilkan motivasi kerja intern dan prestasi kerja yang tinggi. (c) Pengetahuan tentang hasil pekerjaan diperoleh dari umpan balik langsung dari pekerjaan itu sendiri maupun dari penyelia, rekanrekan kerja dan orang lain yang berhubungan dengan pekerjaan itu. Informasi tentang efektivitas usaha ini memberikan hasil tingkat kemangkiran dan pertukaran pekerjaan yang rendah.

Promosi adalah suatu proses perpindahan dari suatu jabatan kejabatan yang lain yang mempunyai status dan tanggung jawab yang lebih tinggi, hal ini seiring diikuti oleh penerimaan imbalan yang lebih tinggi namun ada pula tidak diikuti komponen tersebut yang disebut dengan promosi kering (Martoyo, 1992). Ada beberapa alasan mengapa di dalam setiap organisasi diadakan promosi, yaitu: a) Untuk mempertinggi semangat kerja. b) Untuk menjalin stabilitas pegawai. Terdapat beberapa kriteria yang perlu dipertimbangkan dalam rangka mempromosikan tenaga kerja. Strauss dan Sayles (1982), menyebutkan kriteria yang baik untuk promosi adalah bajik (prestasi sekarang), kemampuan (potensi, prestasi masa depan) dan senioritas (pengalaman). Sedangkan menurut Siswanto (1989) kriteria untuk promosi adalah senioritas, kualifikasi pendidikan, prestasi kerja, karsa dan daya cipta, tingkat loyalitas, kejujuran dan supelitas.

Promosi sering tidak dapat dilaksanakan karenatidak adanya jabatan dalam pekerjaan tersebut. Karyawan yang tidak berhasil untuk mengisi lowongan kerja internal harus diberitahu mengapa mereka tidak memperoleh kesempatan mengembangkan karir. Untuk itu perusahaan perlu menjelaskan mengapa mereka tidak dipilih, menunjukkan kegiatan-kegiatan yang dapat mengembangkan karir dan mempertimbangkan promosi yang lain bila mereka kompeten. Untuk mengembangkan karir pegawai, departemen personalia perlu mengadakan pengembangan. Departemen personalia juga perlu mengusulkan dukungan manajemen, memberikan umpan balik kepada karyawan dan membangun suatu lingkungan kerja yang baik. Bagi 
karyawan yang ingin mencapai karir dalam organisasi, mereka harus merasa bahwa organisasi adalah lingkungan yang memuaskan. Promosi diberikan kepada pegawai antara lain untuk mempertinggi semangat kerja dan untuk menjaga stabilitas organisasi. Adanya kesempatan bagi pegawai untuk promosi berakibat berkurangnya perputaran pegawai, meningkatnya produktivitas kerja dan menimbulkan kepuasan kerja.

Penyeliaan tenaga kerja adalah suatu usaha sistematik untuk menetapkan standar pelaksanaan dengan tujuan perencanaan, merancang sistem informasi umpan balik, membandingkan aktivitas nyata dengan standar yang telah ditetapkan sebelumnya, menentukan dan mengukur penyimpangan serta mengambil tindakan perbaikan yang diperlukan untuk menjamin bahwa tenaga kerja telah melaksanakan pekerjaan dengan cara paling efisien dan efektif untuk mencapai target produktivitas kerja seirama dengan tujuan perusahaanyang telah ditetapkan (Siswanto, 1987). Kemampuan penyelia untuk menunjukkan minat dan perhatian terhadap pegawai akan mempengaruhi kepuasan kerja pegawai. Kepuasan kerja menurut Steers (1985) sampai batas tertentu merupakan hasil dari cara para manajer memperhatikan dan meminta pendapat dan partisipasi bawahannya. Bila karyawan merasa bahwa mereka bagian yang integral dari organisasi dan para atasan mereka merasa secara pribadi memperhatikan kesejahteraan mereka, maka tingkat kepuasan kerja pegawai akan tinggi.
Dalam penelitiannya (Litwin dan Stringer, 1968) dalam Steer (1985) menyimpulkan bahwa iklim yang otoriter dengan sentralisasi pengambilan keputusan sebagian besar ditentukan oleh peraturan dan prosedur, menjurus pada produktivitas yang rendah, menghasilkan sedikit kepuasan dan kreativitas serta menimbulkan sikap yang negatif terhadap kelompok kerja. Sebaliknya iklim yang bersifat kekeluargaan dengan tekanan pada hubungan antar pribadi yang baik diantara para pekerja biasanya akan menjurus pada kepuasan kerja yang tinggi, sikap positif dalam kelompok kerja, perilaku kreatif yang cukup besar tetapi prestasi kerja rendah. Survey Research Center University Of Michigan yang dikutip Black (1991) menyatakan bahwa tingkah laku para penyelia merupakan faktor pokok di dalam menentukan hasil kelompok yang dipimpinnya. Luthans (1992) disebutkan terdapat dua penyelia yang dapat mempengaruhi kepuasan kerja. Pertama adalah faktor pada karyawan, ini diukur berdasarkan tindakan penyelia yang memperhatikan kesejahteraan karyawan. Hal ini diwujudkan dalam pemerikasaan untuk mengetahui sejauh mana prestasi karyawan, memberikan arahan dan bantuan pada karyawan dan berkomunikasi dengan karyawan pada tingkat personal dan resmi. Kedua adalah partisipasi atau pengaruh, yang dapat digambarkan oleh manajer dimana memungkinkan para pegawai untuk berpartisipasi dalam pembuatan keputusan yang berdampak pada keputusannya. Pendekatan ini bisa 
meghasilkan kekuatan kerja yang lebih tinggi.

Rekan sekerja merupakan lingkungan kerja terdekat yang akan mempengaruhi situasi kerja dan berpengaruh pada motivasi dan prestasi. Rekan sekerja yang menunjukkan sikap bersahabat dan mendukung karyawan akan dapat memberikan kepuasan. Rekan sekerja yang mendukung adalah orang-orang yang mendapatkan lebih dari pada sekedar uang atau prestasi yang berwujud dari dalam kerja (Robbins, 1996). Bagi kebanyakan pegawai, kerja juga mengisi kebutuhan akan interaksi sosial. Oleh karena itu tidaklah mengejutkan bila mempunyai rekan sekerja yang ramah dan mendukung menghantar kekepuasan kerja yang meningkat. Rekan sekerja yang ramah, bersahabat merupakan sumber utama kerja bagi karyawan. Rekan sekerja dapat dijadikan dukungan, masukan, bantuan bagi pekerja secara individu. Rekan sekerja yang baik dapat membuat pekerjaan menjadi lebih menyenangkan.

Kinerja atau prestasi kerja
adalah perbandingan hasil kerja
(output) dengan tindakan yang
dilakukan oleh karyawan (input) yang terus mengalami peningkatan secara kuantitas dan kualitas. Adanya peningkatan kinerja (prestasi kerja) pada diri karyawan dipengaruhi oleh sejumlah faktor, baik dari dalam diri karyawan itu sendiri atau dari luar diri karyawan. Faktor dari dalam diri pegawai salah satunya berupa aspek kerja yang akan membentuk dan miningkatkan motivasi pegawai yang pada akhrnya akan meningkatkan kinerja pegawai. Dalam perusahaan yang mempunyai karyawan dengan tingkat kepuasan motivasi, kecenderungan karyawan itu mempunyai kinerja (prestasi kerja) yang tinggi. Hal ini sesuai dengan pendapat Robbins (1996) dan Luthans (1992) yang mengemukakan bahwa ada hubungan yang positif antara aspek kerja dengan kinerja (prestasi kerja). Dengan adanya pegawai yang mempunyai tingkat kepuasan (motivasi) terhadap aspek kerja akan memotivasi kerja pegawai sehingga pegawai akan dapat meningkatkan produktivitas kerjanya sehingga kinerjanya (prestasi kerjanya) juga meningkat. Peningkatan produktivitas kerja tidak akan berhasil dengan maksimal apabila para pegawai mempunyai tingkat motivasi aspek kerja rendah.

\section{METODE PENELITIAN}

Rancangan dalam penelitian ini termasuk penelitian survey yang digunakan untuk menjelaskan hubungan kausal antar variabelvariabel melalui pengujian hipotesis, maka penelitian ini disebut pula penelitian penjelasan. Penelitian ini dapat melihat akibat dari suatu fenomena dan menguji hubungan sebab akibat dari data-data yang tersedia.penelitian ini dilaksanakan secara purposive di organisasi Rumah Sakit dr. Radjiman Wediodiningrat Lawang Kabupaten Malang. Populasi dalam penelitian adalah individu para pegawai non paramedis Rumah Sakit dr. Radjiman Wediodiningrat Lawang. Karena semua pegawai non paramedis terlibat baik langsung maupun tidak 
langsung, maka sewajarnya jika mereka semua menjadi obyek dalam penelitian ini. Jumlah populasi dalam penelitian ini adalah 108 pegawai non paramedis Rumah Sakit dr. Radjiman Wediodiningrat Lawang, sedangkan untuk menentukan jumlah sampel menggunakan rumus slovin sehingga diperoleh sampel penelitian 53 responden penelitian ditentukan secara Propursive Random Sampling (per bagian tempat kerja).

Variabel dalam penelitian ini terdiri dari dimensi aspek kerja yang meliputi; Gaji, pekerjaan, Promosi, Penyelia, dan Rekan Sekerja sebagai variabel Independen, dan Kinerja Pegawai sebagai variabel Dependen. Data yang diperlukan untuk menggambarkan fenomena, menguji hipotesis, maupun menjelaskan pengaruh antar variabel bersumber dari data primer dan data skunder, sedangkan teknik pengumpulan data melalui kuesioner dengan skala likerd dengan lima alternatif jawaban, wawancara, dan dokumentasi. Data yang terkumpul Sebelum dilakukan analisa data dilakukan maka terlebih dahulu dilakukan uji validitas (kesyahihan) dan reliabilitas (kehandalan) instrumen penelitian yang dalam hal ini adalah kuesioner. Instrumen dikatakan baik kalau valid dan reliabel. Selanjutnya setelah dilakukan uji instrumen (uji validitas dan reliabilitas) dan dinyatakan valid dan reliabel, maka tahap selanjutnya melakukan analisa data. Pada penelitian ini, analisis data dilakukan dengan analisis deskriptif, analisis regresi linear berganda, uji hipotesis, dan selanjutnya akan dilakukan uji model regresi linier berganda yang sebelumnya dilakukan uji asumsi klasik. Sedangkan untuk pengujian hipotesis digunakan uji $\mathrm{F}$ dan $\mathrm{Uji} \mathrm{t}$ semua perhitungan analisis data dilakukan dengan bantuan program SPSS.

\section{HASIL DAN PEMBAHASAN}

Rumah Sakit Jiwa Lawang dibuka secara resmi pada tanggal 23 Juni 1902. Pengerjaan mendirikan rumah sakit ini dimulai tahun 1884 berdasarkan Surat Keputusan Kerajaan Belanda tertanggal 20 Desember 1865 No.100. Sebelum Rumah Sakit Jiwa Lawang dibuka, perawatan pasien mental diserahkan kepada Dinas kesehatan Tentara (Militaire Gezondheids Dienst). Hasil deskripsi masing-masing variabel menunjukkan bahwa sebanyak $64,2 \%$ pegawai non paramedis menyatakan sangat setuju terhadap gaji yang diberikan oleh Rumah Sakit. Sebanyak $77,4 \%$ pegawai non paramedis menyatakan setuju terhadap pekerjaan yang ditekuni di Rumah Sakit. Sebanyak $56,6 \%$ pegawai non paramedis menyatakan setuju dengan promosi yang diberikan oleh Rumah Sakit. Sebanyak $71,7 \%$ pegawai non paramedis menyatakan setuju terhadap penyelian (atasan) di Rumah Sakit. Sebanyak $67,9 \%$ pegawai non paramedis menyatakan setuju terhadap tanggung jawab dalam bekerja di Rumah Sakit. Sebanyak 75,5\% pegawai non paramedis memenuhi jumlah tugas yang diberikan. 
Tabel 1. Koefisien Regresi Coefficients (a)

\begin{tabular}{|c|c|c|c|c|c|c|}
\hline \multirow[t]{2}{*}{ Model } & & \multicolumn{2}{|c|}{$\begin{array}{l}\text { Unstandardized } \\
\text { Coefficients }\end{array}$} & \multirow{2}{*}{ 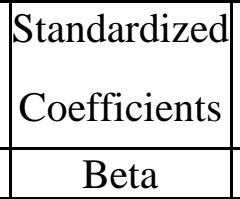 } & \multirow[t]{2}{*}{$\mathrm{t}$} & \multirow[t]{2}{*}{ Sig. } \\
\hline & & & Std. Error & & & \\
\hline 1 & (Constant) & 10.248 & 2.686 & & 3.815 & .000 \\
\hline & Gaji (X1) & .031 & .138 & .035 & .224 & .824 \\
\hline & Pekeriaan (X2) & .097 & .123 & .133 & .788 & .434 \\
\hline & Promosi (X3) & -.142 & .117 & -.224 & -1.208 & .233 \\
\hline & Penyelia (X4) & .208 & .140 & .241 & 1.478 & .146 \\
\hline & Rekan Sekerja (X5) & .325 & .148 & .370 & 2.196 & .033 \\
\hline
\end{tabular}

a Dependent Variable: Kinerja Pegawai (Y)

Dari hasil analisis infersial didapatkan semua variabel dari aspek kerja berpengaruh terhadap tingkat kinerja pegawai non paramedis. Koefisien regresi dari masing-masing variabel adalah gaji $(0,031)$, pekerjaan $(0,097)$, promosi $(-0,142)$, penyelia $(0,208)$ dan rekan sekerja $(0,325)$. Namun, diantara yang variabel yang berpengaruh tersebut, yang signifikan hanya variabel rekan sekerja (X5). Variabel yang paling dominan diperoleh dari nilai beta (standardized coefficients), yaitu varibel rekan sekerja (X5) sebesar 0,370. Sehingga pernyataan hipotesis ketiga yang berbunyi diduga diantara variabel aspek kerja, variabel gaji yang mempunyai pengaruh dominan terhadap kinerja pegawai non paramedis Rumah Sakit dr.Radjiman Wediodiningrat Lawang ditolak. Dari hasil analisis regresi khususnya pada model summary dapat dilihat pada tabel berikut:

Tabel 2. Analisis Korelasi dan Determinasi Model Summary (b)

\begin{tabular}{|c|c|r|c|c|}
\hline Model & $\mathrm{R}$ & $\mathrm{R}$ Square & Adjusted R Square & $\begin{array}{c}\text { Std. Error of the } \\
\text { Estimate }\end{array}$ \\
\hline 1 & $.514(\mathrm{a})$ & .264 & .185 & 1.788 \\
\hline
\end{tabular}

a Predictors: (Constant), Rekan Sekerja (X5), Pekerjaan (X2), Gaji (X1), Penyelia (X4), Promosi (X3) b Dependent Variable: Kinerja Pegawai (Y)

Berdasarkan tabel di atas diperoleh angka $\mathrm{R}$ sebesar 0,514. Hal ini menunjukkan bahwa terjadi hubungan positif yang cukup kuat antara aspek kerja terhadap kinerja pegawai non medis pada Rumah Sakit dr. Radjiman Wediodiningrat Lawang. Berdasarkan tabel di atas pula diperoleh angka Adjusted $\mathrm{R}$ Square sebesar 0,185 atau $18,5 \%$. Hal ini menunjukkan bahwa prsentase sumbangan pengaruh variabel bebas (gaji, pekerjaan, promosi, penyelia, dan rekan sekerja) terhadap variabel terikat (kinerja pegawai) hanya sebesar $18,5 \%$. Sedangkan sisanya $81,5 \% \%$ dipengaruhi atau dijelaskan oleh variabel lain yang tidak dimasukkan dalam model penelitian ini. Dari hasil uji regresi linier berganda dan regresi linier sederhana menunjukkan bahwa aspek kerja yang terdiri dari variabel gaji, pekerjaan, promosi, penyelia dan rekan sekerja secara bersama-sama (simultan) mempunyai pengaruh yang signifikan dengan kinerja. Hal ini 
mendukung pendapat dari Luthans (1992), Wekley \& Yulk (1992), Gibson (1995), dan Gilmer (1996) dalam As'ad (1998) bahwa aspek kerja yang berupa gaji, pekerjaan, promosi, penyelia dan rekan sekerja dapat mempengaruhi kinerja. Dilihat dari variabel aspek kerja yang mempengaruhi kinerja, maka koefisien regresi yang tertinggi merupakan faktor yang perubahannya paling berpengaruh terhadap kinerja. Yang memberikan sumbangan terbesar pada kepuasan kerja secara berurutan yaitu (1) rekan sekerja, (2) penyelia, (3) pekerjaan, (4) promosi dan (5) gaji. Rekan sekerja mempunyai nilai yang terbesar yang berpengaruh terhadap tingkat kinerja pegawai non paramedis Rumah Sakit dr. Radjiman Wediodiningrat Lawang dibanding yang lain. Rekan sekerja yang mendukung adalah yang mendapatkan lebih daripada sekedar uang atau prestasi yang berwujud dari dalam kerja (Robbins, 1996). Oleh karena rekan sekerja, kekompakan dan bekerja secara team work memang sangat dibutuhkan oleh organisasi dengan sistem pelayanan yang saling terkait antara sesama pegawai non paramedis. Dalam mendorong motivasi kerja rekan kerja akan mengantar ke kepuasan yang meningkat dan pada akhirnya akan memdorong kinerja pelayanan terhadap pasien yang terlihat dari sedikitnya keluhan-keluhan terhadap pihak rumah sakit. Rekan sekerja yang ramah, bersahabat merupakan sumber utama kerja bagi karyawan. Rekan sekerja dapat dijadikan dukungan, masukan, bantuan bagi pekerja secara individu. Bila hubungan antar rekan sekerja tidak berjalan dengan baik, akan berdampak negatif pada kepuasan kerja karyawan (Luthans,1992).

Hasil penelitian ini

menunjukkan bahwa rekan sekerja para pegawai non paramedis memberikan sumbangan terbesar pada tingkat kinerja pegawai non medis di Rumah Sakit dr. Radjiman Wediodiningrat Lawang. Untuk memberikan kinerja secara menyeluruh variabel-variabel lain perlu diperhatikan, terutama yang pengaruhnya terhadap kinerja masih rendah. Berdasarkan tingkat aspek kerja, variabel gaji dan promosi mempunyai pengaruh yang rendah dibandingkan dengan yang lain. Manajemen perlu memperhatikan kedua variabel ini karena pegawai non medis Rumah Sakit dr. Radjiman Wediodiningrat Lawang dalam variabel ini berpengaruh kecil terhadap kinerja dibandingkan variabel rekan sekerja, penyelia dan pekerjaan. Iklim kerja yang bersifat kekeluargaan dengan tekanan ada hubungan antar pribadi yang baik diantara para pegawai biasanya akan menjurus pada kelompok informal yang tinggi, sikap positif dalam kelompok kerja, perilaku kreatif yang cukup besar tetapi kinerjanya (prestasi kerja) rendah (Litwin dan Stringer, 1968 dalam Steers, 1985). Dalam Black (1991) menyatakan bahwa tingkah laku para penyelia merupakan faktor pokok di dalam menentukan hasil kelompok yang dipimpinnya.

Gaji merupakan variabel penting bagi karyawan. Menurut Storner dan Wankel (1986) imbalan berupa uang merupakan imbalan yang dianggap paling penting di tempat kerja. Pegawai akan merasakan bahwa gaji diterimanya adil apabila ratio antara usaha dan imbalan seimbang dengan ratio individu yang dibandingkannya. (Gibson, 1995). Oleh sebab itu orientasi dengan pembanding di luar organisasi sangat penting untuk dapat memuaskan pegawai. Sistem penggajian yang memperhatikan prestasi individu dapat memotivasi pegawai untuk berprestasi. Peningkatan gaji dikaitkan dengan prestasi dapat merupakan strategi memotivasi yang bermanfaat (Mobley, 1986). Pemberian gaji secara pukul rata dapat menyebabkan kekecewaan bagi pegawai yang prestasi kerjanya baik tetapi mendapat imbalan sama dengan pegawai yang prestasinya kurang baik. Pembayaran gaji merupakan bentuk imbaan yang 
paling nyata yang dapat dikendalikan oleh organisasi, kerenanya memiliki dampak yang tidak kecil artinya. Kegagalan memberikan imbalan yang lebih besar kepada prestasi kerja yang baik dapat mengakibatkan pergantian pegawai diantara orang-orang yang ingin dipertahankan organisasi (Mobley, 1986). Lebih lanjut menurut Mobley (1986) pegawai yang tidak puas dapat juga bertahan dalam organisasi dan melakukan bentuk pengunduran diri seperti mangkir, lesu dalam pekerjaan, sabotase dan memberikan kualitas pekerjaan yang rendah. Gaji untuk pegawai non paramedis yang memadai dan kompetitif perlu dipertimbangkan oleh manajemen agar dapat memuaskan para pegawai tersebut. Pendapat tentang gaji yang dirasakan pegawai dapat menjadi pertimbangan bagi manajemen untuk memperbaiki sistem penggajian di Rumah Sakit dr. Radjiman Wediodiningrat Lawang. Hal ini juga menjadi petunjuk bahwa masalah gaji pegawai merupakan faktor penting untuk diperhatikan oleh manajemen.

Dari hasil penelitian maka terdapat beberapa hal yang perlu dipertimbangkan oleh manajemen, yaitu: (1) Para pegawai non paramedis mempunyai orientasi tentang gaji di luar Rumah Sakit dr. Radjiman Wediodiningrat Lawang. Manajemen perlu memonitor pemberian gaji di luar Rumah Sakit dr. Radjiman Wediodiningrat Lawang, dan manajemen juga perlu menjelaskan kepada pegawai non paramedis perihal pelaksanaan upaya-upaya yang telah diberikan organisasi dalam rangka meningkatkan motivasi kerja pegawai non paramedis yang pada giliranya akan miningkatkan kinerjanya dan memperbaiki tingkat pelayanan kepada pasien (masyarakat). Upaya itu misalnya jasa pelayanan, asuransi kesehatan, dana pensiun, pemberian seragam. (2) Para pegawai non paramedis mempunyai orientasi terhadap pembanding intern.
Penghargaan individual atas kinerja dan sumbangan pegawai terhadap Rumah Sakit perlu mendapat perhatian. Ada inidikasi menurunnya semangat kerja pegawai disebabkan pegawai yang berprestasi dihargai sama dengan yang kurang berprestasi. (3) Untuk meningkatkan pelayanan rumah sakit, pihak manajemen perlu mempertimbangkan pemberian gaji yang kompetitif dengan memperhitungkan komponen gaji yang lazim diperhitungkan di instansi lain, misalnya: penghargaan terhadap prestasi, insentif lain yang belum dipertimbangkan. Pegawai juga membandingkan kesejahteraan di rumah sakit lain seperti wisata gratis. Hal ini perlu diperhatikan karena perasaan adil dalam penggajian antara lain muncul dalam pikiran pegawai dengan membandingkan penggajian di instansi lain.

Variabel promosi merupakan variabel yang penting untuk diperhatikan sesudah variabel gaji. Variabel promosi pengaruhnya terhadap tingkat kinerja lebih rendah dibandingkan dengan variabel rekan sekerja, penyelia dan pekerjaan. Dalam Mobley (1986) menunjukkan bahwa kurangnya kesempatan promosi dinyatakan sebagai alasan pengunduran diri yang utama. Promosi untuk pegawai non paramedis dengan jenjang struktural terbatas untuk beberapa orang. Promosi untuk pengembangan ketrampilan dan pengetahuan masih terbuka untuk semua pegawai non paramedis. Pegawai non paramedis perlu mengetahui jenjang karir apa yang dapat mereka capai dan bagaimana cara mencapainya. Pegawai tersebut yang tidak berhasil untuk mengisi lowongan kerja internal harus diberi tahu mengapa mereka tidak memperoleh kesempatan karir (Handoko, 1992). Untuk pengembangan karir pegawai, bagian SDM perlu mengadakan pelatihan dan pengembangan bagi karyawan yang ingin mencapai karir dalam organisasi mereka harus 
merasa bahwa organisasi adalah lingkungan yang memuaskan (Handoko, 1992).

Variabel pekerjaan sumbangannya terhadap kinerja pegawai non paramedis Rumah Sakit dr. Radjiman Wediodiningrat Lawang di bawah variabel rekan sekerja dan penyelia. Pekerjaan dapat menyumbang pada kepuasan, motivasi dan prestasi tinggi serta tingkat kemangkiran dan perputaran kerja yang rendah (Scheil, 1992). Pegawai non paramedis di Rumah Sakit dr. Radjiman Wediodiningrat Lawang mempunyai penghargaan dan sikap positif terhadap pekerjaan sebagai pegawai. Menurut Schein (1992) pekerjaan yang menghasilkan motivasi dan prestasi yang tinggi yaitu bila pekerjaan itu dialami sebagai sesuatu yang berarti, dia dapat bertanggungjawab secara pribadi dan dapat memastikan secara teratur bagaimana hasil pekerjaannnya. Menurut Mobley (1986) variabel pekerjaan terhadap kinerja merupakan salah satu faktor utama yang menentukan kinerja itu akan meningkat atau stagnan. Pengaruh kinerja terhadap jenis (type) pekerjaan merupakan suatu evaluasi yang berorientasi sekarang yang mencakup suatu perbandingan nilai-nilai karyawan dan apa yang dirasakan oleh karyawan mengenai pekerjaannya (Locke, 1975 dalam Mobley, 1986). Sejauh pekerjaan itu dirasakan memenuhi apa yang sangat bernilai bagi seseorang, tingkat kinerjanya akan meningkat. Sejauh pekerjaan itu tidak dirasakan memenuhi apa yang menjadi penilaian seseorang, aspek motivasi terhadap pekerjaan berkurang. Lebih lanjut Mobley (1986) menjelaskan bahwa konsep terhadap motivasi dalam meningkatkan kinerja itu penting untuk memahami kediplinan kerja dan hubungannya dengan pergantian karyawan.

Variabel penyelia memberikan sumbangan yang besar terhadap tingkat kinerja tetapi masih di bawah variabel rekan sekerja. Kemampuan penyelia untuk menunjukkan minat dan perhatian terhadap pegawai akan mempengaruhi tingkat prestasi kerja (kinerja). Menurut Steers (1985) sampai batas waktu tertentu kepuasan kinerja merupakan hasil dari cara atasan memperhatikan dan meminta pendapat dan partisipasi bawahannya. Bila pegawai merasa bahwa mereka bagian yang integral dari organisasi dan para atasan merasa secara pribadi memperhatikan kesejahteraan mereka, maka akan merasa dihargai oleh atasan yang akhirnya kinerjanya akan meningkat.

\section{KESIMPULAN}

Dari hasil analisis infersial didapatkan semua variabel dari aspek kerja berpengaruh terhadap tingkat kinerja paramedis (perawat dan bidan). Koefisien regresi dari masing-masing variabel adalah gaji,pekerjaan, promosi,penyelia dan rekan sekerja. Namun, diantara yang variabel yang berpengaruh tersebut, yang signifikan hanya variabel rekan sekerja. Variabel yang paling dominan diperoleh dari nilai beta (standardized coefficients), yaitu varibel rekan sekerja. Sehingga pernyataan hipotesis ketiga ditolak. Untuk mengukur tingkat kepuasan kerja pegawai non paramedis Rumah Sakit dr.Radjiman Wediodiningrat Lawang dapat dengan melihat pengaruh aspek kerja yang terdiri dari gaji, pekerjaan, promosi, penyelia dan rekan sekerja yang diukur secara simultan maupun parsial. Untuk mengukur hasil kerja dapat dilihat dari tingkat kepuasan kerja pegawai yang pada akhirnya akan memperbaiki kinerja individu dan kelompok tenaga non paramedic. 
DAFTAR PUSTAKA

As'ad, M. 1998. Seri Ilmu Sumber Daya Manusia, Psikologi Industri, Liberty, Yogyakarta.

Baedhowi. 2007. Manajemen Sumber Daya Manusia. Semarang: Pelita Insani.

Black, Jr. 1991. Manajemen dan Supervisor, PT Pustaka Binaman Pressindo. Jakarta

Braid, RW 1991. Pengaruh Penggajian: Memotivasi Pegawai Seri Ilmu dan Seni Manajemen Bisnis, PT Gramedia. Jakarta.

Gibson, et al. 1996. Organisasi,perilaku, Struktur, Proses. Diterjemahkan Nunuk Adiarni. Binarupa Aksara. Jakarta.

Gujarati \& Zain. 1997. Ekonometrika Dasar. Penerbit Erlangga. Jakarta. Handoko, T H (1982) Manajemen Personalia dan Sumber Daya Manusia. BPFE. Yogyakarta.

Heidjirahman dan Husnan, S. 1990. Manajemen Personalia. BPFE. Yogyakarta.

Joseph, J \& Deshpande, SP. 1997. The Impact Ethical Climate on Job Satisfaction on Nurses, Health Care Manage Rev.,Aspen Publishers, Inc. Vol 22, No 1.

Luthans, F. Organizational Behavior. Mc Graw Hill. USA Manullang, M (1984) Manajemen Personalia. Aksara Baru. Jakarta. Martoyo, S .1994. Manajemen Sumber Daya Manusia. BPFE. Yogyakarta.

Mobley .1986. Motivasi dan Kepribadian Diterjemahkan Nini
Iman. Pustaka Budiman Pressindo. Jakarta.

Purnomosidhi, $\quad$ B. 1990.

Pengembangan Kepuasan Kerja:

Studi Tentang Pengaruh Iklim

OrganisasiTerhadap Kepuasan

Kerja Pegawai Universitas

Brawijaya. Laporan Penelitian

Universitas Brawijaya. Malang.

Priyatno, Dwi, 2008, Mandiri Belajar

SPSS, Penerbit Mediakom, Yogyakarta.

Robbins, SP 1996. Organization

Behavior. Diterjemahkan

Hadayana Rojaatmaka. PT

Prenhallindo. Jakarta.

Satriyo 1997. Pengaruh Perilaku Pemimpin, Iklim Organisasi, dan Kinerja Terhadap Kepuasan:Suatu Studi Pada Kantor Dinas Pendapatan Daerah Propinsi Daerah Tingkat I Jawa Timur Cabang Malang. Tesis, Program Pascasarjana Universitas Brawijaya. Malang.

Schein, EH .1992.Psikologi Organisasi. PT Pustaka Binaman Pressindo. Jakarta.

Siagian, S .1984. Organisasi, Kepemimpinan \& Perilaku Administrasi. Gunung Agung. Jakarta.

Sinungan, M .1992. Produktivitas, Apa dan Bagaimana. Bumi Aksara. Jakarta. Siswanto, B (1989) Manajemen Tenaga Kerja. Sinar Baru. Bandung. Stoner, James, A. F (1986) Manajemen Erlangga. Jakarta.

Westerman, J \& Donoghue, P.1994. Pengolahan Sumber Daya Manusia. Diterjemahkan Suparman, Bimi Aksara, Jakarta. 
REFERENSI: Jurnal Ilmu Manajemen dan Akuntansi Vol.5 No.2 Desember 2017

Wexley, K N \& Yukl, G A .1992. Perilaku Organisasi dan Psikologi Personalia. Diterjemahkan Shobarudin Rineka Cipta, Jakarta.

Widiastari, S. 1994. Analisis FaktorKepuasan Kerja Perawat di Bagian Rawat Inap Rumah
Sakot Panti Rapih Yogyakarta, Tesis Program Pasca Sarjana UGM Yogyakarta.

Winarni, S .1995. Analisis Kepuasan Kerja Pada PT Kusuma Sandang Mekarjaya Yogyakarta, Tesis Program Pascasarjana UGN Yogyakarta. 